Egger, $\mathrm{P}$.

Trade economists have for long considered gravity models to estimate unexhausted potentials for bilateral tra de. Similar to the discrepancy between "nomal" and "actual" bilateral trade, one may ask the question about the difference between "nomal" and ac tual bilateral multina tional a ctivity. However, with multinational a ctivity, zero bilateral data and heteroscedasticity are very important, even more so than with trade data. Therefore, this paper suggests using genera lized linear rather than log-linear models to spec ify "nomal" FDI and obta in estimates of unexhausted FDI potentials. I use pa nel data on Austria's bila teral multinational a c tivity a cross 25 countries and 7 country-blocs, 4 sectors and 13 years to illustrate the disadvantage of log-linear model estimation at quasimaximum likelihood estimation.

The FIW Research Reports show the results of the three thematic work packages 'Export of Services', 'Foreign Direct Investment' and 'Competitiveness', that were commissioned by the Austrian Federal Ministry of Economic s and Labour (BMWA) within the framework of the "Research Centre Intemational Economics" in November 2006. 
口ÖSTERREICHISCHES INSTITUT FÜR WIRTSCHAFTSFORSCHUNG

\section{Bilateral FDI Potentials for Austria}

\section{Peter Egger}

Projektkoordination: Yvonne Wolfmayr, Irene Langer 


\section{Bilateral FDI Potentials for Austria Peter Egger}

Studie im Rahmen des Leitprojekts "Forschungsschwerpunkt Internationale Wirtschaft (FIW)" des Österreichischen Instituts für Wirtschaftsforschung im Auftrag des Bundesministeriums für Wirtschaft und Arbeit

Arbeitspaket No2 Direktinvestitionen: Modul 1, Teilmodul 1.3 Projektkoordination: Yvonne Wolfmayr, Irene Langer April 2008 


\section{Bilateral FDI Potentials for Austria}

Contents

Page

Das Wichtigste in Kürze

Abstract

1. Introduction

2. Econometric approach

3. Data and estimation

4. FDI potentials

5. Conclusions 21

6. References 



\section{Bilateral FDI Potentials for Austria}

\section{Peter Egger}

Adress: Ifo Institut für Wirtschaftsforschung und LMU

Phone: +49 (089) 9224-1238

Fax: +49 (089) 985369

E-mail: egger@ifo.de

\section{Das Wichtigste in Kürze}

Ein, wenn nicht das wichtigste empirische Anwendungsfeld von Modellen für bilaterale Warenströme - so genannte Gravitationsmodelle - ist die Schätzung unausgeschöpfter Potentiale des Warenhandels. Die Aktivität multinationaler Unternehmen und insbesondere deren Direktinvestitionen im Ausland werden von Handelsökonomen mittlerweile als ähnlich wichtig wie der Austausch von Waren angesehen: multinationale Unternehmen schaffen Beschäftigung im Inland durch rasches Auslandswachstum, führen zu einer Veränderung der Nachfrage nach ungebildeten relativ $\mathrm{zu}$ gebildeten Arbeitskräften und beeinflussen das Wettbewerbsumfeld sowohl in Mutter- wie Gastländern.

Es liegł demnach nahe - ähnlich wie bei Warenströmen - nach „natürlichen“, auf Basis ökonomischer Kräfte vorhersagbaren Direktinvestitionsströmen sowie nach realisierten Strömen zU fragen. Nach Maßgabe ökonomischer Mechanismen liegł dort ein unausgeschöpftes Potential an Direktinvestitionen vor, wo tatsächliche hinter natürlichen bilateralen Direktinvestitionen zurückbleiben.

Eine entscheidende Voraussetzung für die konsistente Schätzung unausgeschöpfter Direktinvestitionspotentiale ist - wie auch bei Warenströmen - die Verwendung geeigneter Schätzverfahren. Bei Direktinvestitionen sind mehr noch als bei Handelsströmen Modelle gefragt, welche das zahlreiche Auftreten von Null-Strömen erlauben. In dieser Arbeit wird argumentiert, dass Modelle für Zähldaten die nötigen Eigenschaften aufweisen. In einer Anwendung auf österreichische Direktinvestitionen auf Sektorebene zeigł sich, dass Ansätze für Zähldaten zu fundamental anderen Schlüssen als log-lineare Modelle in Bezug auf Direktinvestitionspotentiale führen 
können. Die Diskrepanz zwischen log-linearen Modellen und solchen für Zähldaten ergibt sich aus der unbefriedigenden Vernachlässigung von Nullen bei log-linearen Modellen für bilaterale Direktinvestitionsdaten.

Für das Jahr 2005 nehmen Deutschland, die Niederlande, Großbritannien und die Tschechische Republik je den ersten Rang hinsichtlich unausgeschöpfter Direktinvestitionspotentiale in den Sektoren "Landwirtschaft, verarbeitendes Gewerbe, Energie und Baugewerbe", "Handel und Gewerbe", "Tourismus, Realitätenwesen, Bildungs- und Gesundheitswesen" und "Banken und Versicherungen" ein. Unter den zehn wichtigsten Ländern mit unausgeschöpften Direktinvestitionspotentialen sind generell zentral- und osteuropäische Länder prominent vertreten. 


\section{Abstract}

Trade economists have for long considered gravity models to estimate unexhausted potentials for bilateral trade. Similar to the discrepancy between "normal" and "actual" bilateral trade, one may ask the question about the difference between "normal" and actual bilateral multinational activity. However, with multinational activity, zero bilateral data and heteroscedasticity are very important, even more so than with trade data. Therefore, this paper suggests using generalized linear rather than log-linear models to specify "normal" FDI and obtain estimates of unexhausted FDI potentials. I use panel data on Austria's bilateral multinational activity across 25 countries and 7 country-blocs, 4 sectors and 13 years to illustrate the disadvantage of log-linear model estimation at quasi-maximum likelihood estimation.

JEL-code: F14; F15; F21; F23

Keywords: Multinational activity; Gravity model; Trade potentials 



\section{Introduction}

One if not the most important field of application for gravity models of bilateral trade is its use for estimating trade potentials (see Baldwin, 1994, or Baldwin, Francois and Portes, 1997, for early and very influential examples)'1). Recently, the contributions of Eaton and Kortum (2002) and Anderson and van Wincoop (2003) entailed significant scientific progress, suggesting gravity model frameworks that allow for the estimation of comparative static effects of bilateral trade frictions consistent with multi-country general equilibrium. However, to date there are only a few examples where gravity models have been used for that purpose. It is still true that most of the applications do not go beyond parameter estimation and prediction of "natural" and residual trade flows.

In general equilibrium, bilateral multinational enterprise (MNE) activity such as foreign direct investment (FDI) or foreign affiliate sales depend on the same exogenous determinants as bilateral trade flows (see Bergstrand and Egger, 2007) and may be described by empirical gravity models as well (see Brenton, Di Mauro and Lücke, 1999, and Dupasquier and Osakwe, 2006, for earlier examples). Naturally, one might then be interested in "natural" versus "potential" bilateral levels of MNE activity. However, statistics on MNE - especially ones on bilateral FDI at the country and even more so at the sector level - look much more like Swiss cheese due to an exuberant number of zero entries than bilateral trade statistics. Such a mass of zeros may not be ignored and precludes estimating log-linear models. However, zeros may be conveniently modeled in a generalized linear framework such as Poisson models (as recommended by Santos Silva and Tenreyro, 2006), negative-binomial or other models. This paper illustrates how generalized linear models can be used for estimating "natural" bilateral MNE activity and unexhausted potentials. The

1) The term gravity model relates to theoretical or empirical specifications which model bilateral trade flows as a function of two countries' gross domestic products and trade costs. The latter is often approximated by bilateral distance. In the most parsimonious form and expressed in levels, bilateral export flows of some country (i) in some country $j$ depend on the product of a constant and three variables: the gross domestic product of $i$, the gross domestic product of $j$, and distance between (i) and $j$. This functional form is identical to Newton's law of gravity which is why similar bilateral trade models are referred to as gravity models. 
arguments are illustrated by using a panel dataset for bilateral Austrian MNE activity in 25 individual countries and 7 country-blocs, 4 sectors and 13 years.

The remainder of the paper is organized as follows. The next section discusses issues with the econometric approach for modeling bilateral MNE activity at the country or sector level with particular emphasis on "potential" and "actual" activity. Section 3 introduces the dataset and summarizes the key findings for a comparison of loglinear versus generalized linear model estimation. The last section concludes with a summary of the most important findings. 


\section{Econometric approach}

Log-linear models are not suitable if the dependent variable exhibits zero values which are not assigned randomly. This seems to be the case for bilateral trade flows (see Felbermayr and Kohler, 2006, and Helpman, Melitz and Rubinstein, 2008). However, zeros are even much more important with bilateral data on foreign direct investment. Previous research on trade flows illustrated in particular the suitability of pseudo-maximum likelihood generalized linear models as compared to other approaches (see Santos Silva and Tenreyro, 2006; and Westerlund and Wilhelmsson, 2006). In particular, advantages include the suitability for particular cases of heteroscedastic and/or non-normally distributed disturbances in comparison to competing methods. I will illustrate that the deviation from log-linear modeling of bilateral FDI can have fundamental consequences about the conclusions with regard to potential as compared to actual relationships among country-pairs. Another advantage of the generalized linear models summarized in this section for empirical work is that they may be estimated easily either with cross-section or with panel data cum fixed effects ${ }^{2}$ ).

Generalized linear pseudo-maximum likelihood estimators (PMLE) are available for various functional forms. For instance, for a single country-pair (ii) ((i) is the parent and (j) the host country) and cross-sectional data, the conditional mean of bilateral FDI may be defined as $E\left(A_{i t} \mid X_{i t}\right)=g\left(X_{Y}\right)$, where $A$ are bilateral foreign assets or FDI stocks, $\mathbf{X}$ is the matrix of explanatory variables (possibly including indicator variables for country-specific fixed effects), $\mathbf{y}$ is the corresponding parameter vector, and $\mathrm{g}(\bullet)$ is a function which depends on the shape of the chosen form of distribution. Let us refer to the element of $g(\bullet)$ for a single country-pair by $g_{i j}(\bullet)$. The first-order conditions of a generalized linear model for bilateral FDI are then given by (see McCullagh and Nelder, 1989; Cameron, Pravin and Trivedi, 1998; Cameron and Trivedi, 2005; Winkelmann, 2003)3):

2) In general, fixed effects tend to bias non-linear estimators, in particular, if the cross-section is large and the time dimension is small. For instance, this would be true for Heckman's (1979) model of sample selection and other forms of Tobit models.

3) Generalized linear models are based on a distribution function of the linearized exponential family such as the Gaussian, Poisson, negative binomial, or Gamma distributions. Note that (1) can be 
(1) $\quad \sum_{i=1}^{N} \sum_{j=1}^{N}\left[A_{i j}-g_{i j}(\cdot)\right] \mathbf{X}_{i j}=0$.

With heteroscedastic disturbances, one should rely on the Eicker-White sandwich estimator of the variance-covariance matrix for testing (see Cameron and Trivedi, 2005). If the mean of the data is proportional to the variance, one may adopt the Poisson version of (1). In case that the variance is larger, other models such as the negative binomial model are preferable.

estimated as a standard generalized linear model as long as the assumed distribution function belongs to that family. 


\section{Data and estimation}

In the application, I use three alternative variables to measure Austria's bilateral MNE activity at the sector level: foreign assets in $m n €$, the corresponding number of foreign subsidiaries, and the number of employees. In Tables 1 - 3, I report averages of the three concepts of MNE activity across the 4 sectors, the 32 countries, and the 13 years of the sample, respectively ${ }^{4}$. Notice that those averages reflect averages of Austria's outward activity across sectors, host countries, and years. For instance, the column at the center of Table 1 indicates that - in the average host country and year - Austrian MNEs held almost 28 foreign subsidiaries in the sector covering NACE industry classifications 01 - 45 (this includes agriculture, manufacturing, energy production and construction), while they held less than 7 foreign subsidiaries in the sector covering NACE classifications 65 - 67 (banking and insurance). The center column in Table 2 suggests that Austria's MNEs hold particularly many foreign subsidiaries in large and/or adjacent markets (very much in line with how flows should behave in a gravity model). Finally, Table 3 indicates that MNE activity of any kind grew dramatically over the covered time span.

Table 1: Descriptive statistics for Austrian MNE activities by sector (1993-2005) (averages over host countries and years)

\begin{tabular}{|c|c|c|c|c|}
\hline & & $\begin{array}{l}\text { Foreign assets } \\
\text { in } m n €\end{array}$ & $\begin{array}{r}\text { Number of } \\
\text { foreign } \\
\text { affiliates }\end{array}$ & $\begin{array}{r}\text { Number of } \\
\text { foreign } \\
\text { employees }\end{array}$ \\
\hline NACE & Sector aggregate & & & \\
\hline $01-45$ & $\begin{array}{l}\text { Agriculture, manufacturing, } \\
\text { energy production, construction }\end{array}$ & 214.0 & 27.9 & $4,023.3$ \\
\hline $50-52$ & Trade & 99.8 & 17.3 & $1,224.8$ \\
\hline 55-64 and 70-99 & Other services" & 256.1 & 16.1 & 621.2 \\
\hline $65-67$ & Financial and insurance services & 186.3 & 6.9 & $1,144.3$ \\
\hline
\end{tabular}

$\left.{ }^{4}\right)$ Obviously, some of the "countries" are in fact country-blocs. These have not been aggregated by the author but by the Austrian National Bank. The reason for aggregation at the country and sector level is to respect confidentiality and to keep individual investors and investments anonymous. 
Table 2: Descriptive statistics for Austrian MNE activities

by country (1993-2005)

(averages over sectors and years)

Foreign assets Number of Number of

in $m n €$ foreign affiliates foreign employees

\begin{tabular}{|c|c|c|c|}
\hline Belgium & 90.5 & 7.9 & 571.8 \\
\hline Bulgaria & 103.1 & 5.4 & $1,099.0$ \\
\hline Canada & 54.0 & 7.6 & 393.5 \\
\hline Switzerland & 676.4 & 54.6 & $1,376.4$ \\
\hline China & 65.8 & 10.7 & 467.0 \\
\hline Czech Republic & 842.9 & 99.3 & $15,478.2$ \\
\hline Germany & $1,638.0$ & 135.6 & $11,904.2$ \\
\hline Denmark & 69.6 & 3.8 & 139.3 \\
\hline Spain & 43.5 & 12.0 & 645.9 \\
\hline France & 178.2 & 23.9 & $1,337.5$ \\
\hline United Kingdom & 591.0 & 28.2 & $1,803.4$ \\
\hline Croatia & 246.5 & 21.8 & $2,441.5$ \\
\hline Hungary & 887.6 & 166.8 & $19,638.1$ \\
\hline Italy & 219.3 & 27.7 & $1,804.1$ \\
\hline Luxembourg & 41.2 & 5.6 & 21.5 \\
\hline Malta & 171.9 & 3.7 & 19.0 \\
\hline Netherlands & 632.5 & 18.0 & 347.6 \\
\hline Poland & 381.8 & 41.0 & $5,614.4$ \\
\hline Romania & 203.4 & 15.0 & $4,660.6$ \\
\hline Russia & 162.8 & 6.1 & $1,708.9$ \\
\hline Slovakia & 363.3 & 40.3 & $6,073.1$ \\
\hline Slovenia & 234.0 & 26.0 & $1,909.6$ \\
\hline Sweden & 128.9 & 5.4 & 136.8 \\
\hline Ukraine & 33.7 & 5.8 & $1,166.6$ \\
\hline USA & 562.3 & 30.7 & $3,031.5$ \\
\hline AMER') & 68.0 & 9.6 & 620.6 \\
\hline $\mathrm{OECD}^{2}$ ) & 144.0 & 11.1 & 769.9 \\
\hline $\mathrm{OFFSH}^{3}$ ) & 577.9 & 5.4 & 17.1 \\
\hline OSTEU ${ }^{4}$ ) & 23.4 & 8.0 & 478.3 \\
\hline RYUG $^{5}$ ) & 74.3 & 7.5 & 966.8 \\
\hline WESTEU ${ }^{6}$ ) & 280.0 & 15.9 & $1,729.3$ \\
\hline $\mathrm{ROW}^{7}$ ) & 121.3 & 22.0 & $1,944.9$ \\
\hline
\end{tabular}

Source: OeNB. - ') Argentina, Aruba, Brazil, Costa Rica, Chile, Columbia, Ecuador, Guatemala, Honduras, Mexico, Peru, Uruguay, Venezuela. - ${ }^{2}$ ) Japan, New Zealand, Mexico, South Korea, Australia. - ${ }^{3}$ ) Caribean Offshores, Netherlands Antilles, Barbados, Bermuda, Bahamas, Belize, Grenada, Jamaica, St. Kitts \& Nevis, Cayman Islands, Montserrat, Panama, St. Vincent, British Virgin Islands. - ${ }^{4}$ ) Albania, Belarus, Estonia, Latvia, Lithuania, Moldova, Turkey. - ${ }^{5}$ ) Bosnia-Herzegovina, Macedonia, Serbia, Montenegro. - ${ }^{6}$ ) Finland, Greece, Ireland, Portugal, Cyprus, Guernsey, Gibraltar, Isle of Man, Iceland, Jersey, Norway, Vatican City. - ${ }^{7}$ ) United Arab Emirates, Bahrain, Georgia, Indonesia, Israel, Iran, India, Jordan, North Korea, Kuwait, Kazakhstan, Lebanon, Myanmar, Maledives, Malaysia, Philippines,

Pakistan, Saudi-Arabia, Singapore, Thailand, Tajikistan, Taiwan, Uzbekistan, Yemen, Algeria, Egypt, Liberia, Libya, Mauritius, Mozambique, Morocco, Nigeria, Namibia, Tunesia, South Africa, Seychelles. 
Table 3: Descriptive statistics for Austrian

MNE activities by year (1993-2005)

(averages over host countries and sectors)

$\begin{array}{rrrr}\begin{array}{r}\text { Foreign assets } \\ \text { in mn } €\end{array} & \begin{array}{r}\text { Number of } \\ \text { foreign } \\ \text { affiliates }\end{array} & \begin{array}{r}\text { Number of } \\ \text { foreign } \\ \text { employees }\end{array} \\ 1993 & 85.9 & 19.1 & 1,121.4 \\ 1994 & 93.0 & 20.8 & 1,315.6 \\ 1995 & 104.1 & 22.0 & 1,551.0 \\ 1996 & 125.1 & 23.3 & 1,678.5 \\ 1997 & 156.6 & 24.9 & 2,001.0 \\ 1998 & 181.8 & 25.6 & 2,336.0 \\ 1999 & 228.0 & 26.8 & 2,473.6 \\ 2000 & 323.2 & 28.4 & 3,077.3 \\ 2001 & 397.0 & 29.7 & 3,368.8 \\ 2002 & 497.5 & 31.3 & 3,709.0 \\ 2003 & 540.7 & 33.1 & 4,082.1 \\ 2004 & 613.0 & 35.0 & 4,607.1 \\ 2005 & 680.6 & 38.7 & 5,369.6\end{array}$

Source: OeNB.

In none of the main categories (sectors, host countries, or years) was MNE activity of any considered kind zero. However, this does not mean that all cells of the activity vector are non-zero. Overall, there are $4 \cdot 32 \bullet 13=1,664$ observations in the data. Of those, 475 are zero when considering foreign assets in $\mathrm{mn} €$. There are 457 and 470 zeros for the number of foreign subsidiaries and the number of foreign employees, respectively.

I model each of the MNE activity variables as a function of host country GDP and a comprehensive set of year-industry as well as industry-host-country fixed effects. Obviously, it would be preferable to use sector-level GDP and even other variables (such as wage costs, etc.), but such data are not available for a number of countries as large as the one considered here ${ }^{5}$ ). Notice that the inclusion of fixed effects may

5) I have estimated alternative models using sector-specific wages of high-skilled and low-skilled workers in logarithmic form from the International Labor Organization's Standardized ILO October Inquiry 19832003 on the right-hand-side. Using the augmented model, I found that Austria's bilateral MNE activity tends to increase in a host country's skilled workers' wages but to decline in unskilled workers' wages. While this is consistent with predictions from Markusen's (2002) Knowledge-Capital model, I do not report the results here but deliver them upon request. I suppress these findings, since missing wage data lead 
lead to perfect predictions for individual observations. Such observations will be excluded from estimation and be the reason for why the subsequent generalized linear model estimates may rely on less observations than possible.

In formal accounts, the model reads $A_{i t}=f\left(\beta \log G D P_{j t}+\lambda_{i t}+\mu_{i j} ; u_{i j t}\right)$ where the lefthand-side measure is the considered measure of MNE activity in sector (i), host country (j), and year (t) - foreign assets, numbers of foreign affiliates, or numbers of foreign employees, respectively - and the right-hand side includes log GDP times, the unknown elasticity $\beta$ and unknown fixed year-sector $\left(\lambda_{i t}\right)$ as well as fixed sectorhost-country effects $\left(\mu_{i j}\right)$ and the residual $u_{i j t}$. Notice that year-sector effects control for all possible determinants which are common across host countries. Even more importantly, they control for all possible year-sector-specific Austrian determinants (such as factor prices, capital stock, etc.). Fixed sector-country effects control for all possible determinants which are time invariant (such as geographical, institutional, or cultural factors). The functional form $f(\cdot)$ uses either the Poisson or the negative binomial form. For comparison, I also run a log-linear model where $\log A_{i t}$ is used instead of $A_{i t}$ on the left-hand side of the model and $f(\cdot)$ is linear in that case.

to a loss of almost two thirds of the available observations on MNE activity, which renders the results incomparable with the other estimates. 
Table 4: Estimation of a Poisson quasi-maximum-likelihood model

\begin{tabular}{lrrr}
\hline Explanatory variables & $\begin{array}{r}\text { Foreign assets } \\
\text { in } \mathrm{mn} €\end{array}$ & $\begin{array}{r}\text { Number of } \\
\text { foreign } \\
\text { affiliates }\end{array}$ & $\begin{array}{r}\text { Number of } \\
\text { foreign } \\
\text { employees }\end{array}$ \\
\hline log GDP it & 0.029 & 0.023 & $-0.080 *$ \\
& 0.047 & 0.040 & 0.047 \\
Observations & 1,612 & 1,612 & 1,612 \\
Years & 13 & 13 & 13 \\
Sectors & 4 & 4 & 4 \\
Countries & 31 & 31 & 31 \\
log pseudo-likelihood (LL) & $-129,231.7$ & $-13,010.4$ & $-2,046,958.5$ \\
log pseudo-likelihood constant only (LLo) & $-391,985.6$ & $-26,868.1$ & $-4,154,536.7$ \\
& & & 0.000 \\
Wald statistics (p-value) & & 0.000 & 0.000 \\
$\quad$ Year $\times$ sector indicators & 0.000 & 0.000 & \\
Sector $\times$ country indicators & 0.000 & & \\
\hline
\end{tabular}

Notes: ${ }^{* *},{ }^{* *}$, and $*$ indicate that parameters are significantly different from zero according to two-tailed test statistics. Standard errors are corrected for heteroscedasticity. - Source: OeNB, own calculations.

Table 5: Estimation of a negative binomial quasi-maximum-likelihood model

\begin{tabular}{lccr}
\hline Explanatory variables & $\begin{array}{r}\text { Foreign assets } \\
\text { in } \mathrm{mn} €\end{array}$ & $\begin{array}{r}\text { Number of } \\
\text { foreign } \\
\text { affiliates }\end{array}$ & $\begin{array}{r}\text { Number of } \\
\text { foreign } \\
\text { employees }\end{array}$ \\
\hline log GDP it & $0.067^{* * *}$ & $1.0822^{* * *}$ & $0.251^{* * *}$ \\
& 0.024 & 0.092 & 0.024 \\
Observations & 1,417 & 1,417 & 1,417 \\
Years & 13 & 13 & 13 \\
Sectors & 4 & 4 & 4 \\
Countries & 31 & 31 & 31 \\
log pseudo-likelihood (LL) & $-6,376.9$ & $-3,635.0$ & $-8,449.3$ \\
log pseudo-likelihood constant only (LLo) & $-8,361.8$ & $-5,906.5$ & $-10,760.6$ \\
& & & \\
Wald statistics (p-value) & & & 0.000 \\
Year $\times$ sector indicators & 0.000 & 0.000 & 0.000 \\
Sector $\times$ country indicators & 0.000 & 0.000 & \\
\hline
\end{tabular}

Notes: ${ }^{* *}, * *$, and $*$ indicate that parameters are significantly different from zero according to two-tailed test statistics. Standard errors are corrected for heteroscedasticity. - Source: OeNB, own calculations. 
Table 6: Estimation of a log-linear ordinary least-squares model

\begin{tabular}{|c|c|c|c|}
\hline Explanatory variables & $\begin{array}{l}\text { Foreign assets } \\
\text { in } m n €\end{array}$ & $\begin{array}{r}\text { Number of } \\
\text { foreign } \\
\text { affiliates }\end{array}$ & $\begin{array}{r}\text { Number of } \\
\text { foreign } \\
\text { employees }\end{array}$ \\
\hline \multirow[t]{2}{*}{$\overline{\log G D P_{\text {it }}}$} & 0.497 & $0.578^{* * *}$ & 0.843 \\
\hline & 0.562 & 0.206 & 0.653 \\
\hline Observations & 1,137 & 1,155 & 1,142 \\
\hline Years & 13 & 13 & 13 \\
\hline Sectors & 4 & 4 & 4 \\
\hline Countries & 31 & 31 & 31 \\
\hline log likelihood & $-6,376.9$ & $-3,635.0$ & $-1,246.1$ \\
\hline \multicolumn{4}{|l|}{ Wald statistics ( $p$-value) } \\
\hline Year $\times$ sector indicators & 0.000 & 0.000 & 0.000 \\
\hline Sector $\times$ country indicators & 0.000 & 0.000 & 0.000 \\
\hline
\end{tabular}

Tables 4 - 6 summarize the parameter estimates for three different models: Poisson quasi-maximum-likelihood (Table 4); negative binomial quasi-maximum-likelihood (Table 5); and log-linear OLS (Table 6). Since GDP enters in logarithmic form, we may interpret the corresponding parameter estimate in the quasi-maximum-likelihood models as an elasticity.

The results may be interpreted as follows. The negative binomial models should be preferred over their Poisson and OLS counterparts, respectively. Poisson is less suited than negative binomial model estimation since there is over-dispersion in the data (i. e., the mean is not proportional to the variance). Moreover, OLS drops more than a quarter of the observations due to taking a log of zero values of the left-hand-side variable. The reason for why the Poisson and negative binomial model estimates are based on less than 1,664 observations lies in the perfect prediction of some of the fixed effects (see the discussion above).

The negative binomial models indicate that the GDP elasticity of the number of foreign subsidiaries is approximately unity. The elasticities of foreign assets in $\mathrm{mn} €$ and of the number of employees abroad with respect to GDP are smaller. The fixed effects contribute significantly to the explanatory power of the model and should not be excluded or replaced by covariates. The explanatory power of the models in 
Tables 4 and 5 is hard to compare with the one in an OLS model. The latter obtains a within $\mathrm{R}^{2}$ for log total assets in $\mathrm{mn} €$ of about 0.52 (the corresponding $\mathrm{R}^{2}$ figures for numbers of foreign subsidiaries and foreign employees are 0.50 and 0.40 , respectively). Hence, the explanatory power in models is somewhat lower than for bilateral goods trade flows. The pseudo- $\mathrm{R}^{2}$ figures based on the ratio of the loglikelihood values for the Poisson models in Table 4 and of the corresponding constant-only models ${ }^{6}$ ) are fairly high and comparable to those for trade and MNE activity in larger datasets (see Bergstrand and Egger, 2008). The pseudo- $R^{2}$ figures are lower for the negative binomial models than for Poisson, but they should not be used for comparing the two: even the constant-only model performs much better under the negative binomial functional form than under Poisson. Accordingly, the pseudo$\mathrm{R}^{2}$ suggests that GDP and the included fixed effects together contribute relatively less in explanatory power to the negative binomial models than to their Poisson model counterparts. However, Poisson is less suited due to over-dispersion in the data.

6) Define LL as the model log-likelihood and LLo as the constant-only model likelihood. Then, one may define a pseudo- $R^{2}$ as 1-LL/ LLo. For instance, the pseudo- $R^{2}$ is about 0.67 when using foreign assets in $\mathrm{mn}$ $€$ as the dependent variable. However, there are also other concepts for measuring goodness of fit with limited dependent variable models (see Winkelmann, 2003). 



\section{FDI potentials}

With the parameter estimates from Tables 5 and 6 at hand, we may easily determine the level of "natural" or "potential" MNE activity and compare it to the actual one. It will be useful to compare the outcomes for the negative binomial models to their OLS counterparts. Let me display "potential" MNE activity against actual activity for all three concepts using the parameter estimates for the negative binomial model in Table 5. The results are summarized in Figure 1.

As can be seen from all three panels, the observations are clustered around smaller numbers of foreign subsidiaries with corresponding smaller levels of foreign assets and numbers of employees. A good model fit - and, hence, the strong correlation of actual and potential MNE activity - leads to a clustering of the observations along the main diagonal. This is by and large the case with a few exceptions. In particular, there is a number of MNE for which the model predicted less activity than observed. One might refer to this as over-exhausted MNE activity potentials in terms of the estimated model.

Where are unexhausted FDI potentials largest? To answer this question, we need to determine the largest positive deviations from the main diagonal in the top panel of Figure 1. The model identifies the largest unexhausted FDI potential for the Caribbean Islands in the banking and insurance sector and year 2005. Probably more importantly, the model indicates FDI potentials in Germany were and still are unexhausted, in particular, in sector of "other services" (of which tourism is the most important, the other components of that sector, namely education, real estate, and health, are quantitatively less important).

OLS instead would have predicted that the FDI in Germany's tourism industry was almost exhausted both in 1993 and 2005. While OLS identifies unexhausted FDI potentials for the Caribbean's banking and insurance sector in 2005, this observation is by no means among the outstanding ones. In contrast to the negative binomial model, OLS would have concluded that Austria's largest unexhausted FDI potentials are all found for the tourism sector and they appear for the Netherlands (in 2002) and United Kingdom (in 2004 and 2005). In about 47 percent of all predicted FDI 
flows OLS predicted the opposite sign from the negative binomial model for the difference between potential and actual FDI.

Figure 1: Actual vs. potential bilateral MNE activity of Austria in 1993-2005

Bilateral stocks of FDI in $\mathrm{mn} €$

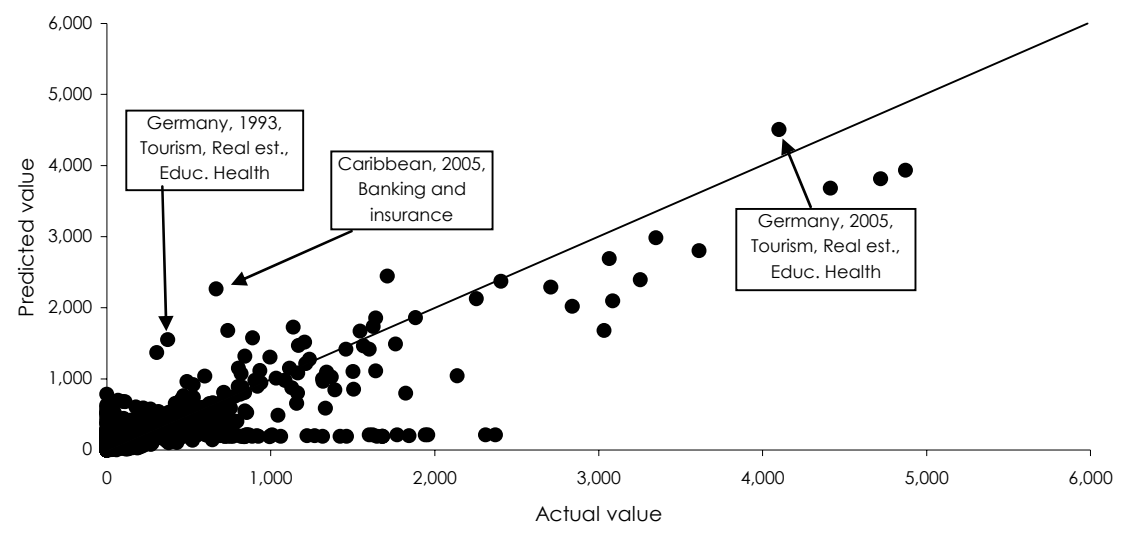

Number of bilateral FDI projects

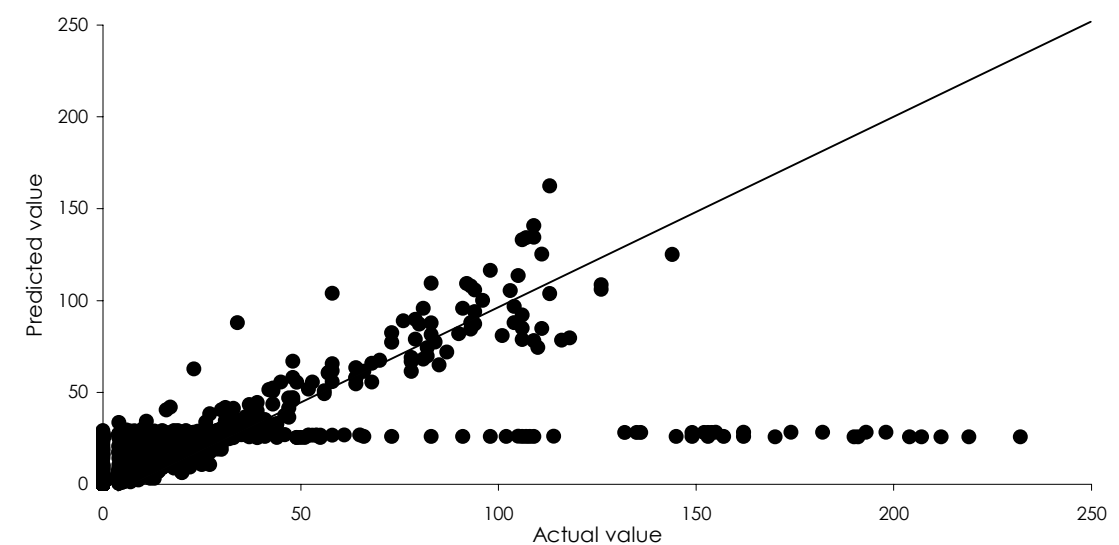

Bilateral number of employees in foreign affiliates

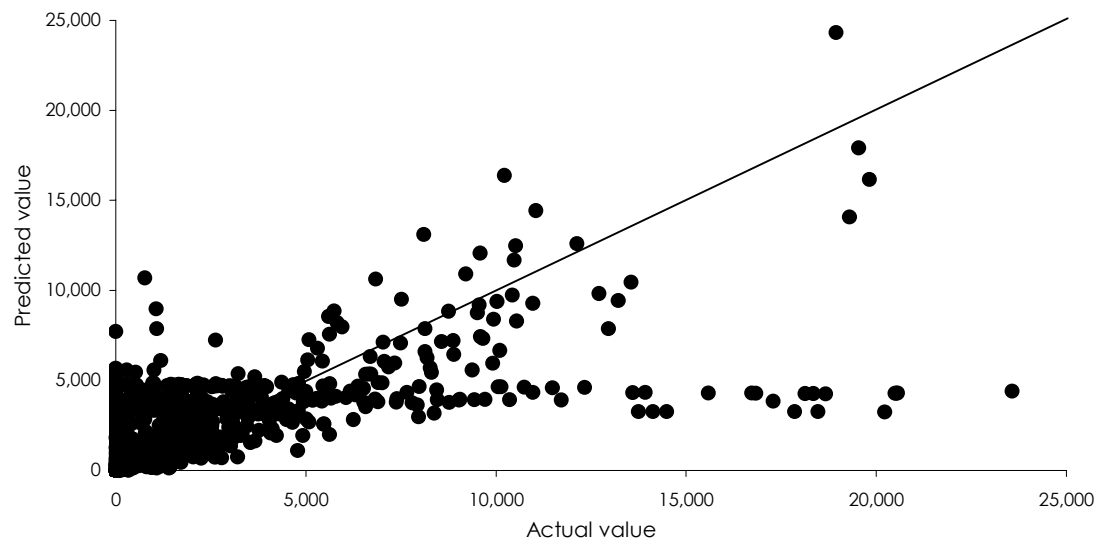

Source: OeNB, own calculations. 
Table 7: Austria's 10 largest unexhausted bilateral FDI stock potentials by sector in $m n €$

Agriculture, manufacturing, energy production, construction

Germany

Switzerland

$1,646.3$

Hungary

$1,491.9$

Romania

$1,459.3$

Czech Republic

870.0

Poland

438.6

Italy

USA

Slovakia

Bulgaria

Trade

United Kingdom

Switzerland

$\mathrm{OECD}^{2}$ )

Spain

Romania

WESTEU ${ }^{3}$ )

RYUG $^{4}$ )

Croatia

Bulgaria

Poland

Other services"

Netherlands

Poland

Denmark

Sweden

Croatia

276.4

France

WESTEU ${ }^{3}$ )

Slovenia

Russia

Financial and insurance services

Croatia

RYUG ${ }^{4}$ )

Ukraine

Poland

Source: OeNB, own calculatons. - ') Hotels and restaurants, transport, post and telecommunication, real estate activities, renting of machinery and equipment, computer and related services, research and development, other business activities, public administration and defence; compulsory social security, education, health and social work, other community, social and personal service activities. - ${ }^{2}$ ) Japan, New Zealand, Mexico, South Korea, Australia. - ${ }^{3}$ ) Finland, Greece, Ireland, Portugal, Cyprus, Guernsey, Gibraltar, Isle of Man, Iceland Jersey, Norway, Vatican City. $\left.-{ }^{4}\right)$ Bosnia-Herzegovina, Macedonia, Serbia, Montenegro. $-^{5}$ ) Albania, Belarus, Estonia, Latvia, Lithuania, Moldova, Turkey. 
While, Figure 1 pools unexhausted MNE activity potentials not only across sectors and host countries but also across years, it seems preferable to look more closely at the cross-sectional variation in a particular recent year. This is done in Table 7, where I report Austria's largest estimated unexhausted FDI potentials in $\mathrm{mn} €$ for each sector considered. What is notable from the table is that, in spite of Austrian multinational's strong presence in Central and Eastern Europe relative to other countries, Central and Eastern European host countries feature prominently in the lists of largest unexhausted FDI stock potentials across all sectors considered. However, three Western European countries-Germany, Netherlands, and United Kingdom-lead the lists of unexhausted FDI potentials for the sectors "agriculture, manufacturing, energy, and construction", "wholesale and retail", and "tourism, real estate, education, and health". Czech Republic exhibits the largest unexhausted FDI potential in the "banking and insurance" sector. 


\section{Conclusions}

Estimating FDI potentials (such as trade potentials) requires suitable functional form assumptions for model estimation. Ignoring zeros of the dependent variable and estimating log-linear models likely leads to unbiased parameter estimates and, as a consequence, to biased estimates for the magnitude and the whereabouts (regarding countries, sectors, and possibly also years) of unexhausted trade potentials.

This paper illustrates that bilateral MNE activity in general and FDI in specific can be predicted quite well by means of parsimonious generalized least squares fixed effects models. In many datasets such as the panel dataset for bilateral Austrian MNE activity at the sector level used here, there will be over-dispersion in MNE activity, i. e., the variance in the data will be far greater than the mean. Econometric models such as the negative binomial model are more suitable in this case than the Poisson model. With the dataset in use, I identified a dramatic difference in the conclusions about unexhausted FDI potentials from negative binomial versus OLS models. This suggests that previous estimates not only of FDI potentials but also of trade potentials may be problematic. 



\section{References}

Anderson, J. E. and van Wincoop, E. (2003), Gravity with gravitas: a solution to the border puzzle, American Economic Review, 93, pp. 170-192.

Baldwin, R. E. (1994), Towards and Integrated Europe, CEPR, London.

Baldwin, R. E., Francois, J. and Portes, R. (1997), The costs and benefits of eastern enlargement, Economic Policy, 24, pp. 125-176.

Brenton, P., Di Mauro, F. and Lücke, M. (1999), Economic integration and FDI: An empirical analysis of foreign investment in the EU and in Central and Eastern Europe, Empirica, 26, pp. 95-121.

Bergstrand, J. H. and Egger, P. (2007), A knowledge-and-physical-capital model of international trade flows, foreign direct investment, and multinational enterprises, Journal of International Economics, 73, pp. 278-308.

Bergstrand, J. H. and Egger, P. (2008), Finding vertical multinational enterprises, unpublished manuscript, University of Notre Dame.

Cameron, A. C., Pravin, C. and Trivedi, P. K. (1998), Regression Analysis of Count Data, University Press: Cambridge.

Cameron, A. C. and Trivedi, P. K. (2005), Microeconometrics: Methods and Applications, Cambridge University Press: New York.

Dupasquier, C. and Osakwe, P. N. (2006), Foreign direct investment in Africa: Performance, challenges, and responsibilities, Journal of Asian Economics, 17, pp. 241-260.

Eaton, J. and Kortum, S. (2002), Technology, geography, and trade, Econometrica, 70, pp. 1741-1779.

Eaton, J. and Tamura, A. (1994), Bilateralism and regionalism in Japanese and U.S. trade and foreign direct investment patterns, Journal of the Japanese and International Economies, 8, pp. 478-510.

Felbermayr, G. and Kohler, W. (2006), Exploring the intensive and extensive margins of world trade, Review of World Economics, 142, pp. 642-674.

Heckman, J. J. (1979), Sample selection bias as a specification error, Econometrica, 47, pp. $153-161$.

Helpman, E., Melitz, M. and Rubinstein, Y. (2008), Estimating trade flows: Trading partners and trading volumes, Quarterly Journal of Economics, forthcoming.

McCullagh, P. and Nelder, J. A. (1989), Generalized Linear Models, 2nd edition, Chapman and Hall: London.

Markusen, J. R. (2002), Multinational Firms and the Theory of International Trade, MIT Press: Cambridge.

Santos Silva, J. M. C. and Tenreyro, S. (2006), The log of gravity, Review of Economics and Statistics, 88 , pp. 641-658. 
Westerlund, J. and Wilhelmsson, F. (2006), Estimating the gravity model without gravity using panel data, unpublished manuscript, Lund University.

Winkelmann, R. (2003), Econometric Analysis of Count Data, Springer: Berlin. 